\title{
Dicliptera aegyptiaca (Acanthaceae), A New Species from Egypt Supported by Morphological Characters and rbcl-based DNA Barcoding
}

\author{
Eman M. Shamso ${ }^{(1)}$, Ahmed S. Fouad ${ }^{(2) \#}$ \\ (1) The Herbarium, Botany and Microbiology Department, Faculty of Science, Cairo \\ University, Giza 12613, Egypt; ${ }^{(2)}$ Botany and Microbiology Department, Faculty of \\ Science, Cairo University, Giza 12613, Egypt.
}

\begin{abstract}
ICLIPTERA aegyptiaca, a new species from Red Sea Coast, Egypt, is described and illustrated. Diagnostic and morphological characters that distinguish it from its allied species $D$. paniculata and an identification key for the two species are provided. The new species differs from $D$. paniculata by having an unbranched stem, a congested inflorescence with dwarf axes $1.5-5 \mathrm{~mm}$ long; subsessile cymules with peduncles $0.5-1 \mathrm{~mm}$ long. rbcl-DNA barcoding is presented for this new taxon for the first time. Phylogentic tree revealed barcode clusters for the two Dicliptera species and recognized significant interspecific variation between them. $D$. aegyptiaca clearly formed one clade strongly supported with a bootstrap value of $100 \%$. Based on characters of morphology, pollen and seeds, the new species was recognized as belonging to the genus Dicliptera. On the other hand, DNA barcoding reflected clustering of all Dicliptera spp. in a large clade while D. aegyptiaca formed a non sister clade showing the utility of DNA barcoding for species identification rather than taxonomy.
\end{abstract}

Keywords: Dicliptera aegyptiaca, DNA barcoding, Egypt, Morphology, New species.

\section{Introduction}

The genus Dicliptera Juss. comprises about 175 species (Daniel, 2009), distributed in tropical and subtropical countries of Asia, Africa and America. Within Acanthaceae, it is placed in the Diclipterinae clade of the "Justicioid" lineage with Hypoestes as a sister to Peristrophe (McDade et al., 2000 a). In the absence of fruits, it is difficult to distinguish between Peristrophe and Dicliptera s. str. (Balkwill, 1996 and Darbyshire \& Vollesen, 2007). Based on the mechanism of capsule dehiscence, Balkwill (1996) and Balkwill et al. $(1985,1986,1996)$ maintained that the two taxa should remain separate, where the capsule is elastic in Dicliptera and inelastic in Peristrophe. In their work, Darbyshire \& Vollesen (2007) transferred all recognized Peristrophe from Tropical East Africa to Dicliptera citing inconsistencies of capsule types and the presence of intermediate forms. The most recent molecular data on the "Justicioid" lineage, Kiel et al. (2017) support Darbyshire \& Vollesen's treatment as sampled species of Dicliptera and
Peristrophe are together monophyletic.

Dicliptera (inclusive of Peristrophe) is characterized by angled stem, opposite leaves, inflorescence panicle-like cymose, with 2-3 inflorescence units (cymules), umbellately arranged, and a resupinate bilabiate corolla. Fruitcapsule clavate, 4 -seeded.

In Egypt, the genus Dicliptera was represented by only one species $D$. paniculata (Peristrophe paniculata), a rare species known only from Gebel Elba and Red Sea Coast of Egypt (Täckholm, 1974; El Hadidi \& Fayed, 1994/ 95; Boulos, 2002, 2009; Shamso, 2010, 2013 and El-Gazzar et al., 2015). As part of the revisionary study of the genus Dicliptera in Egypt, Shamso (2010) recorded Dicliptera paniculata with a wide range of variation in many morphological characters. Most examined specimens represented $D$. paniculata, while some other specimens did not match and were probably an undescribed taxon. Their identities were confirmed by referring to various regional floras 
(Clarke, 1901; Andrews, 1956; Hein, 1966; Abedin et al., 2000; Hedrén, 2006; Ensermu Kelbessa, 2006 and Darbyshire et al., 2010, 2015) and much other relevant literatures (Balkwill, 1996; Balkwill \& Getliffe Norris, 1989; Balkwill et al., 1985, 1986, 1988, 1996; Ensermu Kelbessa, 2003; Darbyshire \& Vollesen, 2007 and Al Hakimi et al., 2017). The specimens were also compared with herbarium specimens and images available in virtual herbaria [Kew Herbarium Catalogue (http://apps.kew.org/ herbcat/navigator.do), African Plant Database (www.tropicos.org) and JSTOR Global Plants (https://plants.jstor.org/)]. It is suggested that these specimens do not match with any of the described species of Dicliptera (incl. Peristrophe) and so are described here as a new species.

DNA barcoding provides an accurate, rapid and time-efficient tool for species identification utilizing short DNA sequences as internal species tags (Hebert, 2003 and Hebert \& Gregory, 2005). The CBOL plant working group (2009) recommended employing $\mathrm{rbcl}$ and/or matk in barcoding of land plants. Compared to matk, rbcl has high amplification success rate; it is the most characterized plastid coding region in GenBank (Newmaster et al., 2006 and Kang et al., 2017). rbcl was used for identification of cryptic species by several research groups (Miwa et al., 2003; Costea \& Stefanovic, 2009; Liu et al., 2013 and Ardiyani et al., 2017).

The aims of this study are to confirm the occurrence of the new taxon Dicliptera aegyptiaca using macro- and micro-morphological data and DNA barcodes, to provide the validating description of the new taxon and to provide a key to the Egyptian species of Dicliptera for easy recognition of the taxa in Egypt.

\section{Materials and Methods}

\section{Plant materials}

The present study was based on examination of several specimens belonging to Dicliptera paniculata kept in the major Egyptian herbaria [Cairo University Herbarium(CAI), the Agricultural Research Centre, Flora and Phytotaxonomy Herbarium (CAIM), National Research Centre, Plant Systematic Herbarium (CAIRC) and Sohag University Herbarium (SHG)]. The new taxon is accompanied by English description (ICBN, 2018: article 39.2).

\section{Pollen and seeds examination}

Samples of pollen and seeds were taken from mature anthers and capsules, respectively. For light microscopy (LM), anthers were boiled for a few minutes in water, macerated in a few drops of an aqueous $10 \%$ solution of $\mathrm{KOH}$ on a clean slide, then stained with Safranin (1\% Safranin solution in $50 \%$ ethanol), mounted in glycerin jelly and observations were made with a Sterico research microscope under (E 40,0.65) using a 16x eye piece, and the seeds were examined with the aid of a dissecting microscope. For SEM studies, both pollen and seeds were mounted onto stubs with double sided adhesive, and then these stubs were sputter-coated with gold (Ion-sputter JFC-1100). After coating, they were examined using JEOL JSM 5400LV scanning electron microscope at $15 \mathrm{KV}$, at the Electron Microscopy Unit, Assiut University. The description of pollen follows the terminology of Hesse et al. (2009) and seed coat terminology follows Barthlott (1981).

\section{DNA barcoding}

Each of Dicliptera paniculata and the new species Dicliptera aegyptiaca were represented by two herbarium specimens. From each specimen, about $20 \mathrm{mg}$ were collected and ground under liquid nitrogen using a mortar and pestle until a fine powder was produced. DNA was extracted using a Qiagen DNeasy kit (Valencia, California, USA) as outlined by manufacturer's protocol with few modifications for herbarium tissues. To the AP1 buffer DDT (Melford Laboratories, UK) at $0.12 \mathrm{mg} / \mathrm{ml}$ and Proteinase K(Sigma) at $0.04 \mathrm{mg} /$ $\mathrm{ml}$ were added and shaken with ground tissue for $60 \mathrm{~min}$ at $65^{\circ} \mathrm{C}$ (de Vere et al., 2012). rbcl amplifications were performed following CBOL Plant Working Group (2009) with the specific primers: 5'-ATGTCACCACAAACAGAAAC3 'and 5'-TCGCATGTACCTGCAGTAGC-3' in a reaction mixture containing $25 \mu$ PCR Master Mix (Bioline), $1 \mu \mathrm{l}$ of each primer and 20-50ng genomic DNA; the volume was completed to $50 \mu 1$ with sterile distilled water. The amplification protocol was $95^{\circ} \mathrm{C}$ for $2 \mathrm{~min}$ followed by 34 cycles of $94^{\circ} \mathrm{C}$ for $1 \mathrm{~min}, 55^{\circ} \mathrm{C}$ for $30 \mathrm{sec}$ and $72^{\circ} \mathrm{C}$ for $1 \mathrm{~min}$, then final extension for $7 \mathrm{~min}$ at $72^{\circ} \mathrm{C}$. Amplification products were purified using the QIAquick PCR Purification Kit (Qiagen, Hilden, Germany) then sequenced with Big-dye terminator chemistry in 3130xl Genetic Analyzer (Life Technologies, California, USA) by following the standard manufacturer's protocol. Forward and reverse sequences were assembled using Codon Code 
Aligner software, v. 7.1.2., the contig sequences were deposited in the GenBank database under accession numbers MH028051 and MG1990431.1 for Dicliptera paniculata and KU947958.1 and KU947961.1 for Dicliptera aegyptiaca. The available online sequences for Hypoestes, Peristrophe and Dicliptera in Gene bank were employed to construct a phylogenetic tree and calculate pairwise distances using Maximum Likelihood (ML) method and Cluster W in MEGA v. 6 (Tamura et al., 2013) based on Tamura 3 parameter model (Tamura, 1992) with gamma distribution. Significance was assessed using 1000 bootstrap replications (Felsenstein, 1985).

\section{Results and Discussion}

Dicliptera aegyptiaca E. Shamso sp. nov.

Type: Egypt: Wadi El Faraied, Red Sea coast 2331'0"N; 3519'60'"E; 12/2/1961; Täckholm et al. 856 (holotype CAI).

Annual herb, 20- 30cm tall, unbranched, rarely with short lateral branches above. Stem angled, glabrous, sparsely strigose with appressed eglandular multicellular hairs on angles and nodes, cystolith present. Leaves rapidly deciduous at lower nodes, blackish-green when dry. Leaf lamina narrowly ovate to lanceolate $15-45 x$ 9$15 \mathrm{~mm}$, attenuate at base, acuminate apex, minutely glandular pubescent, strigose with eglandular multicellular hairs at nerves and margins. Petiole 2-6mm long, strigose (Fig. $1 \mathrm{~A})$. Inflorescence congested in the axils with dwarf axes 1.5$5 \mathrm{~mm}$ long, inflorescence of $(1-) 2-3$ cymules (inflorescence units), umbellately arranged, often compound, with many umbels in each axil. Inflorescence bracts (secondary bracts) 2, subequal, subulate, 3-5x $0.3-0.5 \mathrm{~mm}$, sparsely hairy, hyaline margin at lower half, apex acuminate. Cymule subsessile, the longest peduncle ranges from $0.5-1 \mathrm{~mm}$ long, subtended by 2 - unequal tertiary bracts, the larger one $8-13 \times 0.8-1 \mathrm{~mm}$, linearlanceolate, apex sharply acuminate, the shorter 6- 9x 0.8- 1mm, linear-lanceolate, acuminate apex, pubescent with glandular and sparsely eglandular hairs and hyaline margin at lower half. Each cymule composed of 2- (-3) flowers with 2bracteoles each, maturing sequentially. Bracteoles as bracts, 5- 6x 0.5mm (Fig. 1 B). Calyx whitish green, sparsely hairy outside, tube $0.5-1 \mathrm{~mm}$ long, lobes lanceolate, $3-4 \times 0.5 \mathrm{~mm}$ attenuated to sharp acuminate apex and ciliate margin. Corolla bilabiate, resupinate $8-8.5 \mathrm{~mm}$ long, densely eglandular hairy outside, glabrous inside, tube 3$3.5 \mathrm{~mm}$ long, lower lip tri-fid $4-5 \times 2.5 \mathrm{~mm}$, upper lip retuse to acute $5-5.5 \times 3 \mathrm{~mm}$ (Fig. $1 \mathrm{C}$ ). Stamens 2, epipetalous, filaments 3-5mm long, sparsely hairy, anther-thecae superposed, $0.5 \mathrm{x} 0.3 \mathrm{~mm}$. Pollen grains prolate, medium-sized, with mean polar axis ranges from $32.1-35.8 \mu \mathrm{m}$, mean equatorial diameter ranges from $20-21.9 \mu \mathrm{m}$, circulartriangular in polar view, heterocolpate (tricolporate with paired pseudocolpi parallel to each colporus), both colpori and pseudocolpi of about equal length $(30.7-34.6 \mu \mathrm{m})$, colpal membrane extremely fine reticulate, endoapertures raised circular; exine sculpture foveolate to micro-reticulate (Fig. 2). Ovary oblong $1.5-2 \times 0.5 \mathrm{~mm}$, surrounded by a cupular disc at base, attenuate at apex, eglandular hairy; style filiform, 6- $7 \mathrm{~mm}$ long, glabrous, stigma bi-fid. Capsule 4-seeded, elliptic, 6- 7x $2 \mathrm{~mm}$, densely retrorse eglandular multicellular hairs, with a short rostrum (sterile portion) 1.5$2 \mathrm{~mm}$ long. Seeds discoid, 2x 2-2.2mm, notched at central white hilum, seed surface variously convoluted, indistinct reticulation, covered with minute papillae and tubercles. Tubercles dense around the edges of the seed, with sharp pointed hooks in one or two rows (Fig. 3).

Distribution: Confined to the southern coastal plain of the Red Sea of Egypt.

Specimes examined: Wadi El Faraied, Red

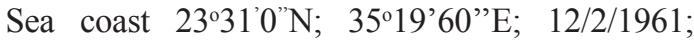
Täckholm et al. 856 (holotype CAI) - Gebel Hamata, Red Sea coast, 7/2/1961; Täckholm et al. 351(CAI).

Habitat: Very rare in sandy and silty moist soils.

Etymology: the specific epithet aegyptiaca refers to Egypt where it was first discovered.

Recognition: Dicliptera aegyptiaca closely resembles $D$. paniculata but differs in its stem unbranched, rarely with short lateral branches above (vs basely and laterally branched), Inflorescence congested at the nodes with dwarf axes 1.5- 5mm long, composed of (1-) $2-3$ cymules, cymule subsessile (vs inflorescence lax panicle-like, opposite at each nodes, with long axes (20-) 30-50mm long, composed of 3- 4 cymules, cymule pedunculate). Pollen dimention 32.135.8 x $20-21.9 \mu \mathrm{m}$, faveolate to micro-reticulate

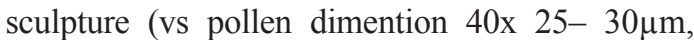
reticulate sculpture). (Fig. 1 and 2). 


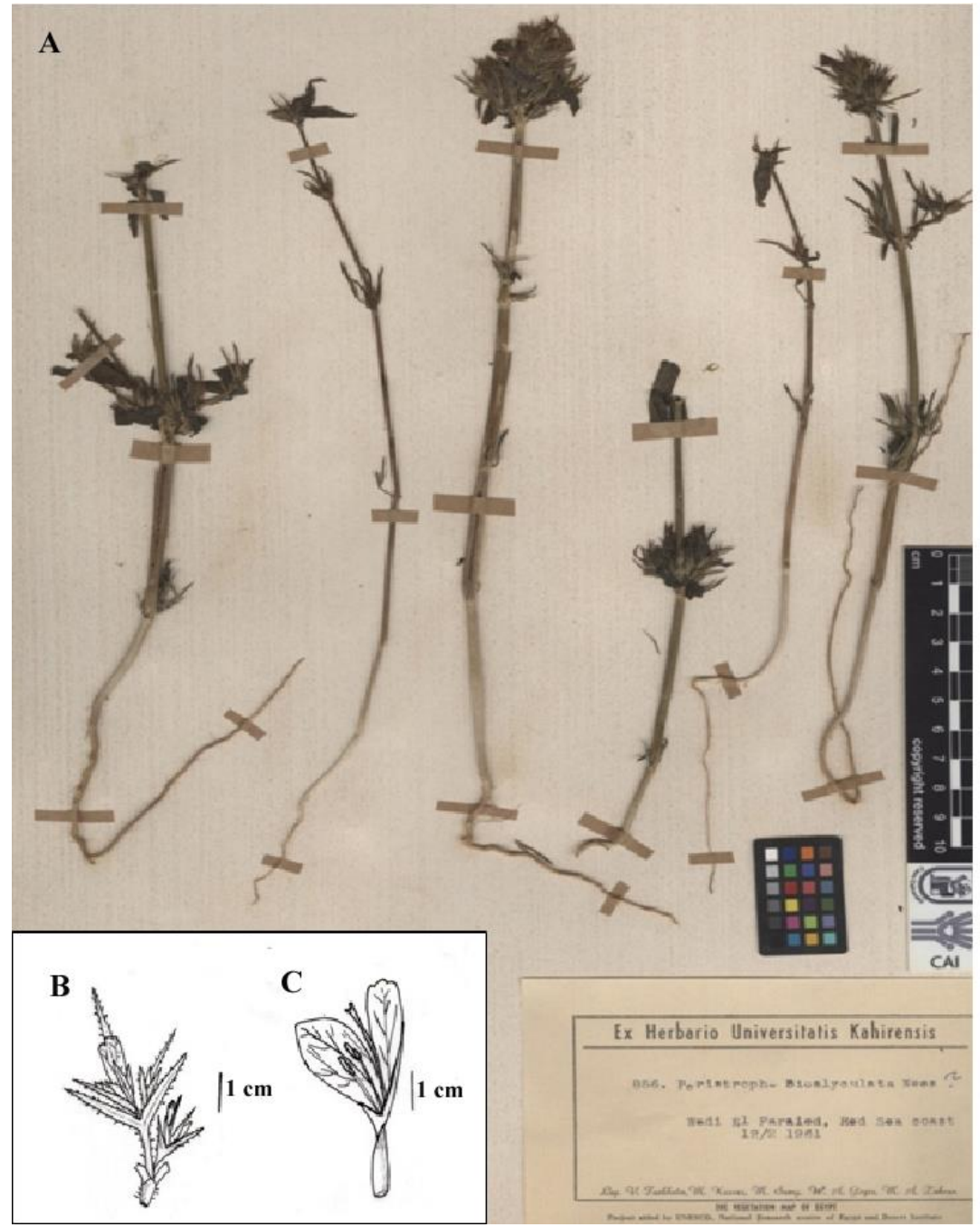

Fig. 1. Dicliptera aegyptiaca E. Shamso (Täckholm et al. 856); A: Image of specimen showing habit, B: congested inflorescence and cymule, C: Rusupinate corolla.

A

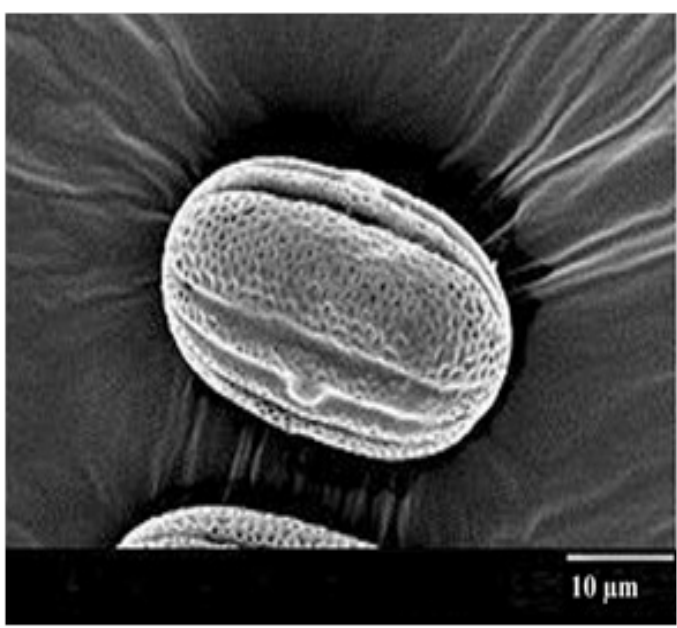

B

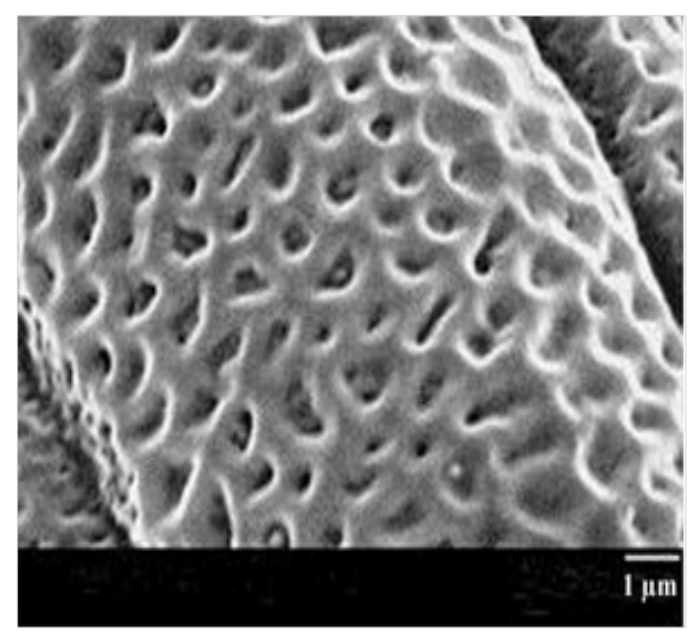

Fig. 2. SEM micrographs of pollen grains of: Dicliptera aegyptiaca; A: Whole grain, equatorial view, B: Exine sculpture. 
A

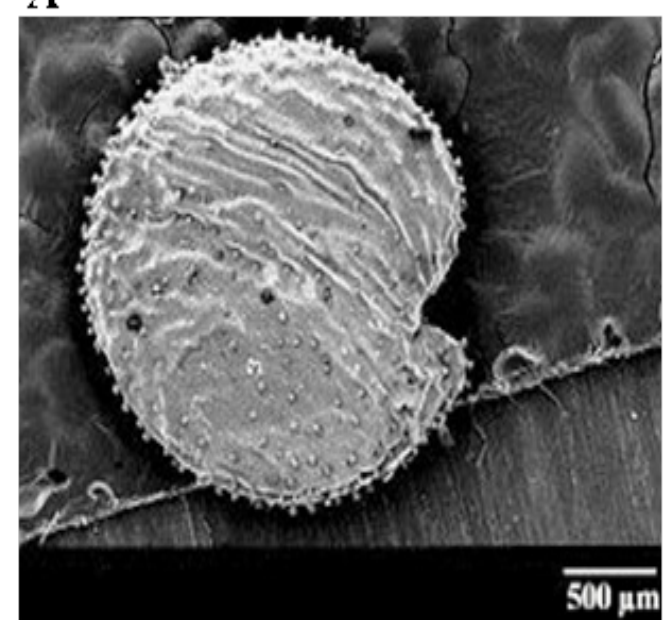

B

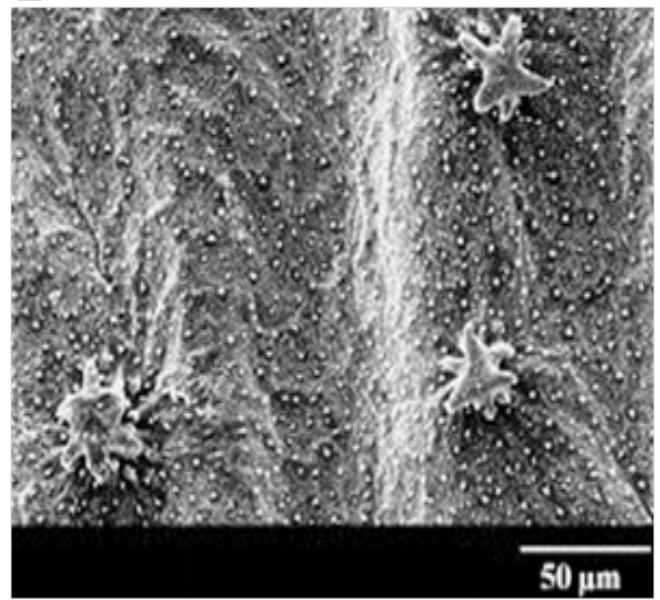

Fig. 3. SEM micrographs of seeds of Dicliptera aegyptiaca; A: Whole seed, B: Testa sculpture.

rbcl-based DNA barcoding provided additional support for Dicliptera aegyptiaca that appeared in the phylogentic tree (Fig. 4), the tree revealed considerable interspecific variation between Dicliptera aegyptiaca and D. paniculata. The new species $D$. aegyptiaca clearly formed one clade strongly supported with a bootstrap value of $100 \%$ while $D$. paniculata along with other Dicliptera spp. formed a non-sister large clade. DNA sequences therefore appear to help recognize groups of individual specimens and are useful for species recognition. The paraphyly of Dicliptera observed in this investigation was also recognized in other Acanthaceae genera including Acanthus using ITS sequences (McDade et al., $2000 \mathrm{~b}$ ) and Justicia using ITS as well as plastid trnL-K, trnS-G and rps16 (Deng et al., 2016).

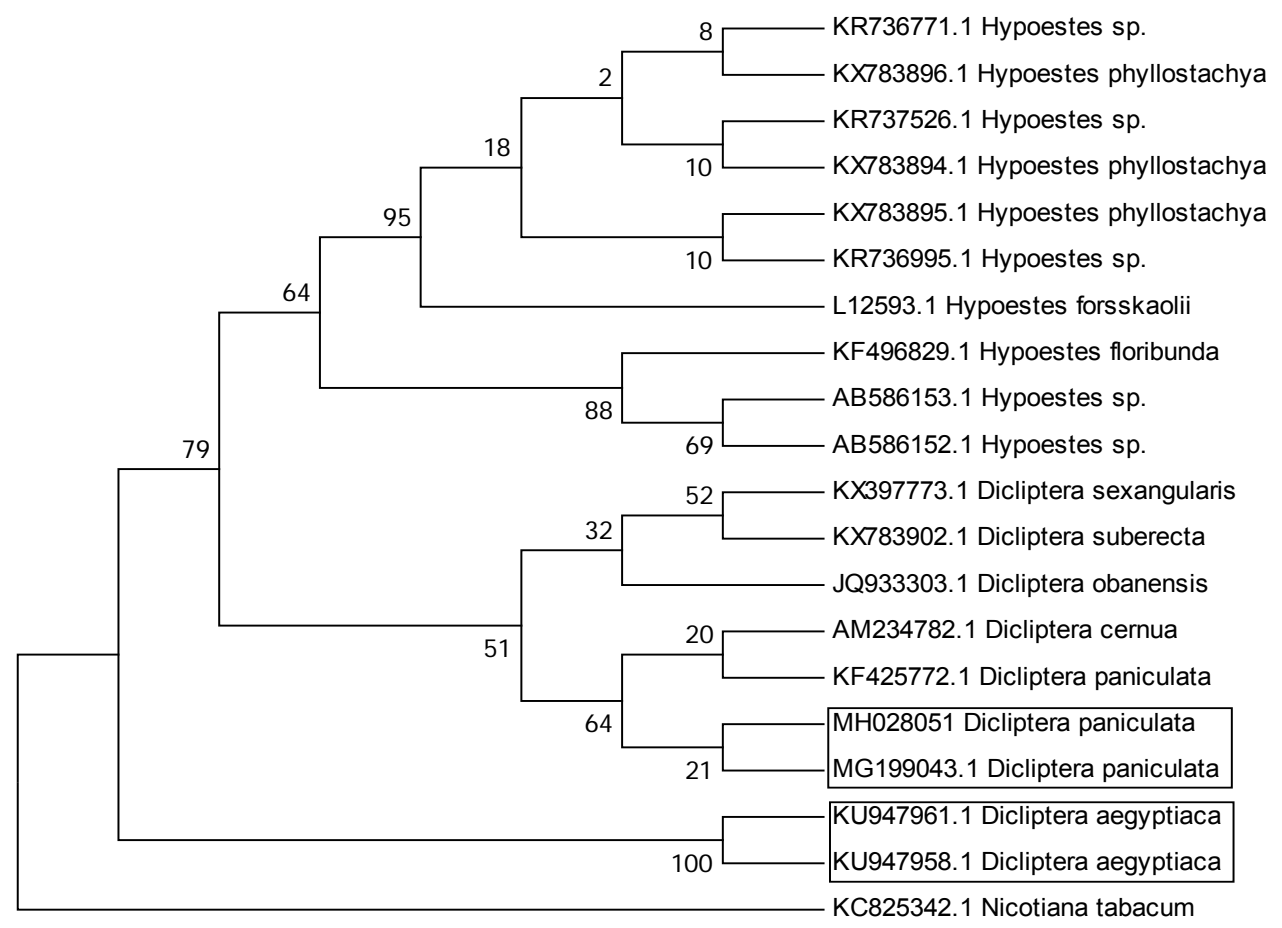

Fig. 4. Phylogenetic tree using Maximum Likelihood method based on Tamura 3 parameter model for rbcl sequences of Hypoestes, Dicliptera and Peristrophe spp. Bootstrap values based on 1000 replications are listed as percentages at branching points. 
Key to the Egyptian species of Dicliptera

1- Stem unbranched, rarely with short lateral branches above. Inflorescence congested at the nodes with short axes, $1.5-5 \mathrm{~mm}$ long. Cymule subsessile, peduncles $0.5-1 \mathrm{~mm}$ long, the larger cymule-bract 8-13x $0.8-1 \mathrm{~mm}$, linear-lanceolate, apex sharply acuminate.

D. aegyptiaca

- Stem basely and laterally branched. Inflorescence in lax panicle- like, with axes (20-) $30-50 \mathrm{~mm}$ long. Cymule pedunculate, peduncles $10-30 \mathrm{~mm}$ long, the larger cymule-bract $12-$ $15 \mathrm{x} 1 \mathrm{~mm}$, oblong -linear, apex sharply acute... D. paniculata

\section{Conclusion}

Results of the present investigation reflect a harmony between morphological features and DNA barcoding in delimiting $D$. aegyptiaca as a new species. On the other hand, appearance of $D$. aegyptiaca as an outgroup for a large clade containing taxa of Dicliptera and Hypoestes supports validity of DNA barcoding in species identification rather than taxonomy. After the introduction of this new species to science, the number of Dicliptera species in Egypt is raised to two.

Acknowledgements: The authors thank Prof Dr. Kevin Balkwill, University of the Witwatersrand, Faculty of Science, Johannesburg, South Africa, for his critical reading, valuable comments and valuable suggestions on the manuscript. Special thanks also go to prof. Dr. Hassna Hossni, Cairo University, Egypt, for revising the manuscript.

\section{References}

Abedin, S., Chaudhary, S., Al-yahya, M.A., Mossa, J.S. and Al Said, M.S. (2000) Acanthaceae, In: "Flora of the Kingdom of Saudi Arabia" Chaudhary, S. (Ed.), illustrated, Volume II(3). Ministry of Agriculture and Water National Herbarium.

Al Hakimi, A., Maideen, H., Saeed, A., Faridah, Q. and Latiff, A. (2017) Pollen and seed morphology of Justicieae (Ruellioideae, Acanthaceae) of Yemen. Flora, 233, 31-50.

Andrews, F.W. (1956) "The Flowering Plants of the Sudan" (Compositae- Graminae) Volume 3. T. Buncle \& Co., Ltd., Arbroath, Scotland, pp. 163191.
Ardiyani, M., Newman, M.F. and Poulsen, A.D. (2017) A new species of Zingiber (Zingiberaceae) east of Wallace's Line. Gardens' Bulletin Singapore, 69, 189-199.

Balkwill, K. (1996) A synopsis of Peristrophe (Acanthaceae) in southern Africa. Bothalia, 26, 8393.

Balkwill, K. and Getliffe Norris, F. (1989) Taxonomic studies in the Acanthaceae. Peristrophe decorticansA new species. South African Journal of Botany, 55, 254-258.

Balkwill, K., Cadman, M.J. and Getliffe Norris, F. (1985) Taxonomic studies in the Acanthaceae. New species of Peristrophe from the Limpopo Valley. South African Journal of Botany, 51, 485-488.

Balkwill, K., Getliffe Norris, F. and Schoonraad, E. (1986) Taxonomic studies in the Acanthaceae: Testa microsculpturing in southern African species of Peristrophe. South African Journal of Botany, 52, 513-520.

Balkwill, K., Getliffe Norris, F. and Balkwill, M.J. (1988) Taxonomic studies in the Acanthaceae: The Peristrophe grandibracteata complex. South African Journal of Botany, 54, 47-54.

Balkwill, K., Getliffe Norris, F. and Balkwill, M.J. (1996) Systematic studies in the Acanthaceae; Dicliptera in southern Africa. Kew Bulletin, 51, 1-61.

Barthlott, W. (1981) Epidermal and seed surface characters of plants: Systematic applicability and some evolutionary aspects. Nordic Journal of Botany, 1, 345-355.

Boulos, L. (2002) "Flora of Egypt" (VerbenaceaeCompositae) Volume 3, pp. 103-104. Al Hadara Publishing, Cairo.

Boulos, L. (2009) "Flora of Egypt" checklist revised annotated edition, pp. 214-215. Al Hadara Publishing, Cairo.

CBOL Plant Working Group (2009) A DNA barcode for land plants. Proceedings of the National Academy of Sciences of the United States of America, 106, 12794-12797.

Clarke, C.B. (1901) Acanthaceae, In: "Flora Capensis", 
Thiselton-Dyer, W.T. (Ed.), pp. 1-92. Volume 5(1). Reeves \& Sons Pty, Ltd, London.

Costea, M. and Stefanović, S. (2009) Molecular phylogeny of Cuscuta californica complex (Convolvulaceae) and a new species from New Mexico and Trans-Pecos. Systematic Botany, 34, 570-579.

Daniel, T.F. (2009) Synopsis of Dicliptera (Acanthaceae) in the Nueva Galicia region of western Mexico with a new species, D. novogaliciana. Proceedings of the California Academy of Sciences, 60, 17-18.

Darbyshire, I. and Vollesen, K. (2007) The transfer of the genus Peristrophe to Dicliptera (Acanthaceae), with a new species described from eastern Africa. Kew Bulletin, 62, 119-128.

Darbyshire, I., Vollesen, K. and Ensermu Kelbessa (2010) Acanthaceae. In: "Flora of Tropical East Africa", Beentje, H.J. (Ed.), part 2. Richmond: Royal Botanic Gardens, Kew.

Darbyshire, I., Vollesen, K. and Ensermu Kelbessa (2015) Acanthaceae. In: "Flora Zambesiaca", Timberlake, J.R. and Martins, E.S. (Eds.), Volume 8(6). Richmond: Royal Botanc Gardens, Kew.

Deng, Y., Gao, C., Xia, N. and Peng, H. (2016) Wuacanthus (Acanthaceae), a new Chinese endemic genus segregated from Justicia (Acanthaceae). Plant Diversity, 38, 312-321.

de Vere, N., Rich, T.C.G., Ford, C.R., Trinder, S.A., Long, C., Moore, C.W., Satterthwaite, D., Davies, H., Allainguillaume, J., Ronca, S., Tatarinova, T., Garbett, H., Walker, K. and Wilkinson, M.J. (2012) DNA Barcoding the native flowering plants and conifers of Wales. PLoS ONE, 7, e37945.

El-Gazzar, A., Khafagi, A.A., El-Husseini, N. and Mostafa, N.A. (2015) Computer-generated keys to the flora of Egypt. 7. The Acanthaceae s.l. Annals of Agriculture Science, 60(2), 257-277.

El Hadidi, M.N. and Fayed, A.A. (1994/95) Materials for excursion Flora of Egypt. Taeckholmia, 15, 147.

Ensermu Kelbessa (2003) Two new species of Acanthaceae from NE tropical Africa and Arabia. Kew Bulletin, 58, 703-712.

Ensermu Kelbessa (2006) Acanthaceae, In: "Flora of Ethiopia \& Eritrea. Gentianaceae to Cyclocheilaceae", I. Hedberg, Ensermu Kelbessa, S. Edwards, Sebsebe Demissew and E. Persson (Eds.), pp. 345-495. Vol. 5. The National Herbarium, Addis Ababa University, Ethiopia and The Department of Systematic Botany, Uppsala, Sweden.

Felsenstein, J. (1985) Confidence limits on phylogenies: An approach using the bootstrap. Evolution, 39, 783-791.

Hebert, P.D.N. (2003) Biological identifications through DNA barcodes. Proceedings of the Royal Society of London B Biological Sciences, 270, 313-321.

Hebert, P.D.N. and Gregory, T.R. (2005) The promise of DNA barcoding for taxonomy. Systematic Biology, 54, 852-859.

Hedrén, M. (2006) Acanthaceae, In: "Flora of Somalia" M. Thulin (Ed.). Volume 3. Royal Botanic Gardens, Kew.

Heine, H. (1966) Acanthaceae. In: "Flore du Gabon". pp. 3-250. Volume 13, Paris: Museum National d'Histoire Naturelle.

Hesse, A., Halbritter, H., Zetter, R., Weber, M., Buchner, R., Andrea, F. and Ulrich, S. (2009) "Pollen Terminology". An illustrated Handbook. Springer Wein, New York.

Kang, Y., Deng, Z., Zang, R. and Lon, W. (2017) DNA barcoding analysis and phylogenetic relationships of tree species in tropical cloud forests. Scientific Reports, 7, 12564.

Kiel, C.A., Daniel, T.F., Darbyshire, I. and McDade, L.A. (2017) Unraveling relatioships in the morphologically diverse and taxonomically challenging "justicioid" lineage (Acanthaceae: Justicieae). Taxon, 66, 645-674.

Liu, Y.J., Newmaster, S.G., Wu, X.J., Liu, Y., Ragupathy, S., Motley, T. and Long, C.L. (2013) Pinellia hunanensis (Araceae), a new species supported by morphometric analysis and DNA barcoding. Phytotaxa, 130, 1-13.

McDade, L.A., Daniel, T.F., Masta, S.E. and Riley, K.M. (2000 a) Phylogenetic relationships within the tribe Justicieae (Acanthaceae): evidence from molecular sequences, morphology and Cytology. Annals of the Missouri Botanical Garden, 87, 435-458. 
McDade, L.A., Masta, S.E., Moody, M.L. and Waters, E. (2000b) Phylogenetic relationships among Acanthaceae: evidence from two genomes. Systematic Botany, 25, 106-121.

Miwa, H., Suhara, J., Kitagawa, N. and Murakami, N. (2003) Biosystematic study of Japanese Conocephalum japonicum (Hepaticae) based on rbcl sequence and allozyme data. Acta Phytotaxonomica et Geobotanica, 54, 37-48.

Newmaster, S.G., Fazekas, A.J.J. and Ragupathy, S. (2006) DNA barcoding in land plants: Evaluation of rbcl in a multigene tiered approach. Canadian Journal of Botany, 84, 335-341.

Shamso, E.M. (2010) A Synoptic revision of Acanthaceae in Egypt, with a new record from Gebel Elba. Taeckholmia, 30, 127-144.
Shamso, E.M. (2013) A Palynological study of Acanthaceae in Egypt and its systematic implication. Egyptian Journal of Botany, 53, 257-272.

Täckholm, V. (1974) "Students' Flora of Egypt". $2^{\text {nd }}$ ed, Cairo University.

Tamura, K. (1992) Estimation of the number of nucleotide substitutions when there are strong transition-transversion and $\mathrm{G}+\mathrm{C}$-content biases. Molecular Biology and Evolution, 9, 678-687.

Tamura, K., Stecher, G., Peterson, D., Filipski, A. and Kumar, S. (2013) MEGA6: Molecular evolutionary genetics analysis version 6.0. Molecular Biology and Evolution, 30, 2725-2729.

\section{Dicliptera aegyptiaca المورفولوجية و تقنية الباركود للأحماض النووية باستخدام جين rbcl}

إيمان شمسو (1)، أحمد فؤاد (2)

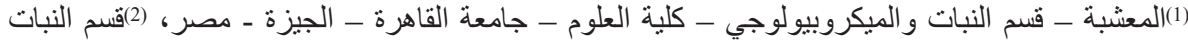

و الميكروبيولوجى - كلية العلوم - جامعة القاهرة - الجيزة - مصر.

أسفرت الدر اسة عن وجود Dicliptera aegyptiaca كنوع جديد بمنطقة ساحل البحر الأحمر بمصر وقد تناول

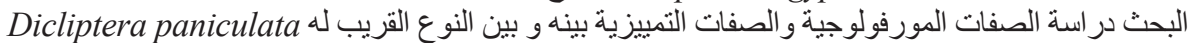

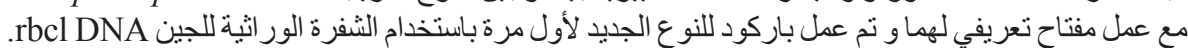

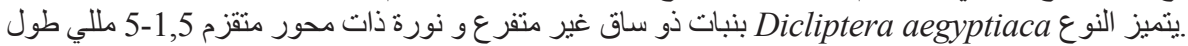

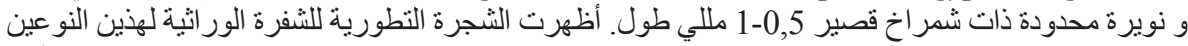

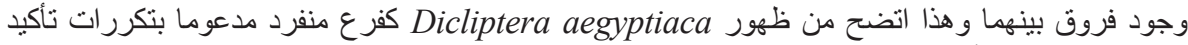

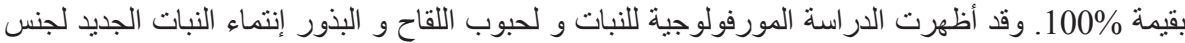

Dicliptera

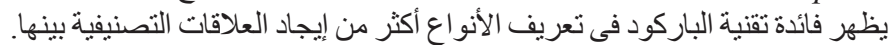

